\title{
Marine Myxobacteria: A Few Good Halophiles
}

\author{
Hanan Albataineh and D. Cole Stevens * \\ Department of BioMolecular Sciences, School of Pharmacy, University of Mississippi, University, MS 38677, \\ USA; haalbata@go.olemiss.edu \\ * Correspondence: stevens@olemiss.edu; Tel.: +1-662-915-5730
}

Received: 10 May 2018; Accepted: 12 June 2018; Published: 14 June 2018

\begin{abstract}
Currently considered an excellent candidate source of novel chemical diversity, the existence of marine myxobacteria was in question less than 20 years ago. This review aims to serve as a roll call for marine myxobacteria and to summarize their unique features when compared to better-known terrestrial myxobacteria. Characteristics for discrimination between obligate halophilic, marine myxobacteria and halotolerant, terrestrial myxobacteria are discussed. The review concludes by highlighting the need for continued discovery and exploration of marine myxobacteria as producers of novel natural products.
\end{abstract}

Keywords: marine myxobacteria; Haliangium ochraceum; Enhygromyxa salina; Plesiocystis pacifica; Haliangium tepidum; Enhygromyxa niigataensis; Pseudenhygromyxa salsuginis; Paraliomyxa miuraensis

\section{Introduction}

In a myxobacterial ecology review published in 1999, Hans Reichenbach asked, "Are there marine myxobacteria?" [1]. Reichenbach's succeeding paragraph provides insight into the uncertainty surrounding marine myxobacteria prior to the routine practice of molecular taxonomy [1]. Two of the major factors contributing to this obscurity were the incorrect assignment of marine Bacteroidetes as lower order myxobacteria or 'Myxobacteria imperfecta' and the ubiquitous distribution and reported isolations of myxobacteria, with varying halotolerances among interfacial environments, such as sediments from beaches and shores [1-9]. While the 16s rRNA sequence analysis has mostly addressed the former, determining that what were considered lower-order marine myxobacteria, were instead Bacteroidetes from the genera Cytophaga and Flavobacterium, the latter continues to obfuscate the distinction between marine and terrestrial myxobacteria [10-12]. Literature concerning the halotolerant myxobacterium Myxococcus fulvus HW-1 (ATCC BAA-855) typifies this issue [13,14]. While M. fulvus HW-1 has been reported to tolerate a salinity as high as 3\% and is listed in the World Register of Marine Species (WoRMS), the strain displays attenuated morphologies and social behaviors that are typical of myxobacteria, such as a fruiting body formation on agar media with low concentrations of seawater or salts $[13,15]$. This review aims to clarify such confusion by highlighting the unique characteristics of halophilic myxobacteria when compared to better-known halotolerant soil myxobacteria, and to encourage further discovery and investigation of marine myxobacteria as a source of structurally unique secondary metabolites.

\section{Characteristics Unique to Marine Myxobacteria}

The recent retrospective analysis of natural product discovery trends reported by Pye et al. concluded that marine organisms are, at least upon discovery, productive sources of novel chemical diversity [16]. Considering this observation, combined with the abundance of biologically active myxobacterial metabolites, we anticipate that an investigation of marine myxobacteria, as producers of secondary metabolites with unique molecular scaffolds and activities, will become a priority for drug 
discovery efforts [17-19]. While limited by the scarcity of cultivable marine myxobacteria, the following characteristics are meant to differentiate known terrestrial, halotolerant myxobacteria from marine, halophilic myxobacteria. These characteristics are centered on halophilicity, multicellular behaviors that have been observed at saline cultivation conditions, phylogeny, and ecology.

Halophilic bacteria rely on the cellular accumulation of organic osmolytes to prevent dehydration in osmotic environments, such as seawater [20,21]. Recently, differing strategies for osmolyte accumulation were reported for Enhygromyxa salina SWB007 and Pleciocystis pacifica SIR-1 ${ }^{\mathrm{T}}$ [22]. While P. pacifica accumulates amino acids to offset osmotic stress, E. salina produces the ubiquitous osmolytes betaine and hydroxyectoine [22]. Interestingly, all of the sequenced myxobacterial halophiles possess a betaine/carnitine/choline transporter (BCCT) or BetT homolog, while the sequenced terrestrial myxobacteria do not, regardless of the reported halotolerances (Table 1). The gene loci that encode solute biosynthetic pathways, such as the confirmed ectoine/hydroxyectoine cluster from E. salina SWB007, cannot currently be considered as critical aspects of marine myxobacteria, as P. pacifica SIR-1 $1^{\mathrm{T}}$ has no such pathway and instead relies on the accumulation of glutamate and glycine to prevent osmotic stress [22]. Excluding M. fulvus HW-1, the only cultivable myxobacteria found to be obligate halophiles have been associated with the 'marine' moniker.

Table 1. Putative osmolyte synthases and transporters from sequenced marine myxobacteria [22]. BCCT_-betaine/carnitine/choline transporter.

\begin{tabular}{|c|c|c|c|c|c|}
\hline Strain & Gene & $\begin{array}{l}\text { NCBI Reference } \\
\text { Sequence }\end{array}$ & Length (aa) & Highest Homology & Identity (\%) \\
\hline \multirow[t]{3}{*}{ H. ochraceum } & ect $C$ & WP_012827762.1 & 142 & $\begin{array}{l}\text { ectoine synthase } \\
\text { (Hydrogenophaga crassostreae) }\end{array}$ & $67 \%$ \\
\hline & bet $T$ & WP_012829907.1 & 538 & $\begin{array}{l}\text { BCCT family transporter } \\
\text { (Desulfovermiculus halophilus) }\end{array}$ & $64 \%$ \\
\hline & sodium/proline symporter & WP_012825704.1 & 598 & $\begin{array}{l}\text { hypothetical protein } \\
\text { (Hymenobacter terrenus) }\end{array}$ & $49 \%$ \\
\hline \multirow[t]{5}{*}{ E. salina } & ect $C$ & WP_106088059.1 & 126 & $\begin{array}{l}\text { ectoine synthase } \\
\text { (Blastopirellula marina) }\end{array}$ & $63 \%$ \\
\hline & ect $D$ & АMH38938.1 & 298 & $\begin{array}{l}\text { ectoine hydroxylase } \\
\text { (Blastopirellula marina) }\end{array}$ & $59 \%$ \\
\hline & bet $T$ & АMH38943.1 & 492 & $\begin{array}{l}\text { BCCT family transporter } \\
\text { (Spingomonas sp. Leaf30) }\end{array}$ & $57 \%$ \\
\hline & sodium/proline symporter & WP_106088061.1 & 481 & $\begin{array}{l}\text { sodium/proline symporter } \\
\text { (Rubinisphaera brasiliensis) }\end{array}$ & $59 \%$ \\
\hline & sodium/glutamate symporter & KIG18073.1 & 469 & $\begin{array}{l}\text { hypothetical protein } \\
\text { (P. pacifica) }\end{array}$ & $64 \%$ \\
\hline \multirow[t]{3}{*}{ P. pacifica } & $\begin{array}{c}\text { bet } T \text { (BCCT } \\
\text { family transporter) }\end{array}$ & EDM75025.1 & 512 & $\begin{array}{l}\text { BCCT family transporter } \\
\text { (Spingomonas sp. Leaf10) }\end{array}$ & $40 \%$ \\
\hline & sodium/proline symporter & WP_006976305.1 & 484 & $\begin{array}{l}\text { sodium/proline symporter } \\
(\text { E. salina) }\end{array}$ & $56 \%$ \\
\hline & $\begin{array}{l}\text { sodium/glutamate symporter } \\
\text { (hypothetical protein) }\end{array}$ & WP_006969752.1 & 478 & $\begin{array}{l}\text { sodium/glutamate symporter } \\
(\text { E. salina) }\end{array}$ & $64 \%$ \\
\hline
\end{tabular}

While among the order of the Myxococcales obligate halophilicity is wholly unique to marine myxobacteria, all myxobacteria participate in unique multicellular behaviors, such as fruiting body formation, social swarming, and organized predation [23-25]. Salinity impedes fruiting body formation of the vast majority of terrestrial and halotolerant myxobacteria [13]. Instead, halotolerant myxobacteria adopt a less complicated, unicellular growth strategy that is independent of cell density, when grown at salinities reflective of seawater conditions [13]. While this strategy provides the resilience required for halotolerant myxobacteria to survive in sandy beaches and shoreline soils, it impedes their ability to thrive in seawater. An outlier, halotolerant Pseudenhygromyxa salsuginis SYR-2 ${ }^{\mathrm{T}}$, designated a 'brackish water myxobacterium', displays fruiting bodies similar to E. salina SHK-1 ${ }^{\mathrm{T}}$ and P. pacifica SIR $-1^{\mathrm{T}}$ at various levels of salinity [26-28]. Synchronized motility, referred to as swarming or gliding, is a defining feature of myxobacteria, has been observed for all marine myxobacteria as well as halotolerant 
myxobacteria, such as M. fulvus HW-1, when grown at varying salinities [12,25-30]. Halophilic myxobacteria swarm in radial patterns with varying amounts of etching occurring on the surface of agar medias [12,26-30]. Typical of terrestrial myxobacteria, marine myxobacteria do not form radial veins or distinct waves when swarming [12,26-30]. Instead, marine myxobacteria aggregate at peripheral bands along the outer circumference of swarms [12,26-30]. Unlike the predation efforts of the model myxobacterium Myxococcus xanthus, organized predation strategies of marine myxobacteria have yet to be explored in detail. While all halophilic myxobacteria discovered to date are capable of lysing a variety of Gram-negative bacteria, only H. ochraceum, H. tepidum, and Enhygromyxa niigatensis are able to lyse Saccharomyces cerevisiae cells [26-30].

The suborder Nannocystineae exclusively consists of halotolerant and halophilic myxobacteria, including all of the discovered cultivable halophilic myxobacteria, with the only potential outlier being the lesser studied, terrestrial Kofleria flava (Figure 1a). Yet again exceptional, M. fulvus HW-1 is the only purported marine myxobacterium to instead belong to the suborder Cystobacterineae (Figure 1a). However, Brinkhoff et al. recently reported a distinct cluster exclusively comprised of marine myxobacteria (Figure 1b) [31]. Aptly designated as the marine myxobacteria cluster (MMC), associated marine myxobacteria were observed primarily from sediment samples and water column samples near the sediment surface worldwide, at salinities ranging from brackish to marine [31]. Interestingly, the myxobacteria distinctly clustered between the MMC and the defined suborders Nannocystineae, Sorangiineae, and Cystobacterineae were from a variety of diverse habitats including volcanic sediment, a wastewater treatment plant, a glacier, a uranium mining waste pile, a microbial biofilm, a hypersaline microbial mat, and various marine sediments [31]. The prevalence of halotolerant and halophilic myxobacteria within the suborder Nannocystineae, the observation of clustered myxobacteria from fluid habitats, and the exclusivity of the MMC provide a unique phylogenetic landscape within the order Myxococcales, where physiological adaptability to environmental volatility seems apparent $[13,25,31,32]$. The observation of phylogeographic separation of marine and terrestrial myxobacteria, reported by Jiang et al., supports this conspicuous delineation [32]. While only recently observed, the MMC and the assumed capacity of the myxobacteria within to produce secondary metabolites exemplifies the need for continued efforts focused on the isolation and cultivation of marine myxobacteria. 


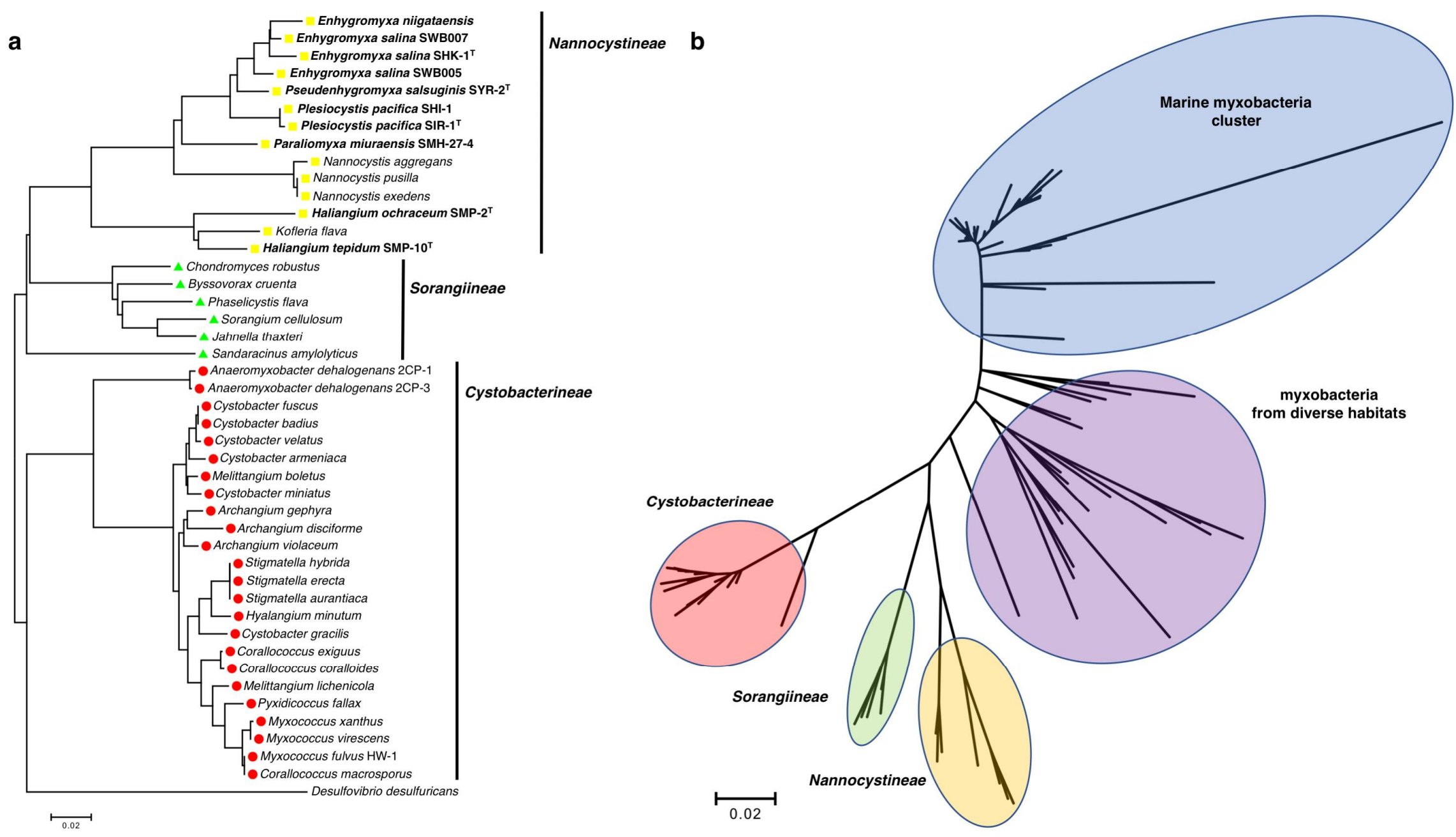

Figure 1. (a) Phylogenetic tree of cultivable Myxococcales with the discussed myxobacteria bolded; (b) Phylogenetic tree of myxobacteria, that includes the MMC and other myxobacteria from [31]. Using MEGA7, 16s rRNA sequences were aligned with ClustalW using general settings (gap opening penalty 15.0; IUB DNA weight matrix), and phylogenetic trees was generated using the neighbor-joining method [33]. 


\section{Haliangium ochraceum}

Originally isolated from a seaweed sample collected from a beach on the Miura Peninsula of Japan and reported as Nannocystis sp. strain SMP-2 in 1998 by Iizuka et al., H. ochraceum, along with what would become Plesiocystis pacifica, was one of the first halophilic marine myxobacteria, which were confirmed by $16 \mathrm{~s}$ rRNA sequencing to be a member of the myxobacterial suborder Nannocystineae [12,29]. The genome for type strain H. ochraceum SMP-2 ${ }^{\mathrm{T}}\left(\mathrm{DSM} 14365^{\mathrm{T}}\right)$ was published in 2010 (NC_013440.1) [34]. Originally cultivated at 30-34 ${ }^{\circ} \mathrm{C}$ on modified VY/2 agar media (Baker's yeast $5 \mathrm{~g} \mathrm{~L}^{-1}$, cyanocobalamin $0.5 \mathrm{mg} \mathrm{L}^{-1}$, agar $15 \mathrm{~g} \mathrm{~L}^{-1}$ ) supplemented with sea water, H. ochraceum was observed to grow at $\mathrm{NaCl}$ concentrations of $0.2-5 \%(w / v)$, with optimal growth between $2-3 \%$ [12,29]. Fudou et al. reported the first discovery of a secondary metabolite from marine myxobacteria, haliangicin, a polyketide with antifungal activity isolated from Haliangium luteum in 2001 [35,36]. Fudou et al. later reclassified Haliangium luteum as H. ochraceum [29]. H. ochraceum has since been reported to produce a variety of haliagicin congeners, as well as the hybrid polyketide-nonribosomal peptide haliamide (Figure 2), via a type-I polyketide synthase pathway and a hybrid polyketide-nonribosomal biosynthetic pathway respectively [37-40]. The features of H. ochraceum, denoted as differentiated from soil myxobacteria, include obligate halophilicity, palmitic acid as a principle fatty acid, and presence of anteiso-branched fatty acids [29]. Fruiting body formation has been reported from both solid and liquid cultures of H. ochraceum, regardless of salinity [13,29]. H. ochraceum swarms form slightly sunken radial bands within agar, generating a tough slime film [29]. Associated with the Haliangiaceae clade of the suborder Nannocystineae, H. ochraceum shows a higher 16S rRNA sequence similarity to terrestrial myxobacteria than other halophilic marine myxobacteria [36,37]. As previously mentioned, H. ochraceum is capable of lysing both Gram-negative bacteria, specifically Escherichia coli and Micrococcus luteus, but also S. cerevisiae [29].<smiles>C=C[C@H]1O[C@]1(C)CC(C)/C(C)=C/C=C(C)\C=C(OC)/C(=C\C(=O)OC)OC</smiles>

haliangicin<smiles>C=C[C@H]1O[C@]1(C)CC(C)/C(C)=C/C=C(C)/C=C(OC)\C(=C/C(=O)OC)OC</smiles>

haliangicin $\mathrm{C}$<smiles>C=C[C@H]1O[C@]1(C)CC(C)/C(C)=C/C=C(C)\C=C(/OC)C(=CC(=O)OC)OC</smiles>

haliangicin B<smiles>C=C[C@H]1O[C@]1(C)CC(C)/C(C)=C/C=C(C)/C=C(OC)\C(=C/C(=O)OC)OC</smiles>

haliangicin D<smiles>C=CC(C)C/C(C)=C/C=C/C(C)NC(=O)c1ccccc1</smiles>

haliamide

Figure 2. Haliangium ochraceum secondary metabolites [35-38]. Of note, cis isomers about the epoxide moiety have also been reported for all of the haliangicins [37]. 


\section{Enhygromyxa salina}

Also discovered by Iizuka et al., E. salina was initially isolated from a lagoon shore on the north coast of Hokkaido, Japan [27]. Three strains of E. salina have been sequenced, including the type strain E. salina SMK-1 ${ }^{\mathrm{T}}$ (DSM 15217 ${ }^{\mathrm{T}}$ ) and strains SWB005 and SWB007 [30,41]. Belonging to the Plesiocystis/Enhygromyxa clade of the suborder Nannocystineae, numerous unique strains of E. salina have been reported [27,30,42]. E. salina produces fruiting bodies varying from white to orange when grown on VY/2 supplemented with salt water [27]. An obligate halophile, E. salina tolerates $\mathrm{NaCl}$ concentrations of $0.1-4.0 \%(w / v)$ with an optimal range of $1.0-2.0 \% \mathrm{NaCl}[27,30]$. However, the numerous strains of E. salina all demonstrate varying ranges of salt tolerance with minimum concentrations as high as $1 \% \mathrm{NaCl}(w / v)$ and maximum concentrations of $7 \% \mathrm{NaCl}[27,30]$. E. salina swarms form circular patterns, leaving deeply etched craters within agar surfaces [27]. While able to survive on media with yeast as the sole nitrogen source, E. salina is only capable of lysing Gram-negative bacteria and is unable to lyse $S$. cereviseae cells [27]. Numerous secondary metabolites have been discovered from a variety of E. salina strains (Figure 3); the activities and biosynthetic assembly of these metabolites have been well reviewed elsewhere [17-19,43,44]. Of note, comparative antiSMASH analysis of the three sequenced strains of E. salina suggests strain SWB005 to be the only sequenced strain of E. salina without a predicted trans-AT polyketide synthase, and strain SWB007 to be the only strain with an identified thiopeptide biosynthetic pathway [45]. Interestingly, only E. salina seems to produce the osmolyte hydroxyectoine, as no other EctD homologue is apparent in the genomes of other sequenced marine myxobacteria (Table 1) [22].

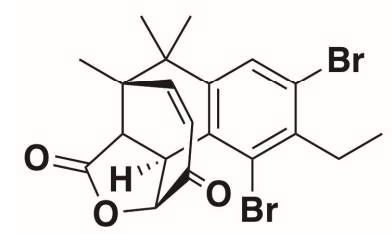

salimabromide

E. salina SWB007

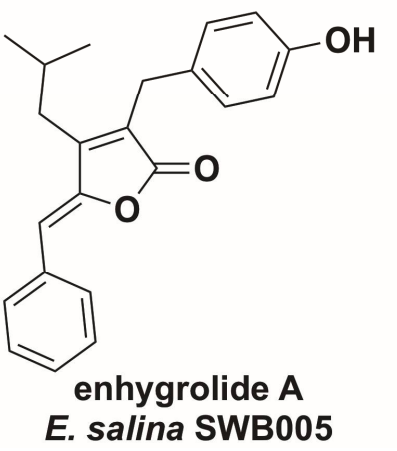

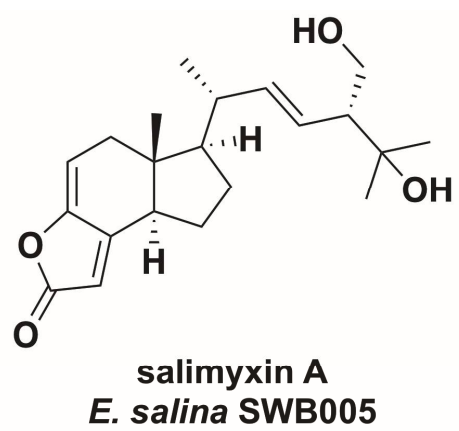

E. salina SWB005

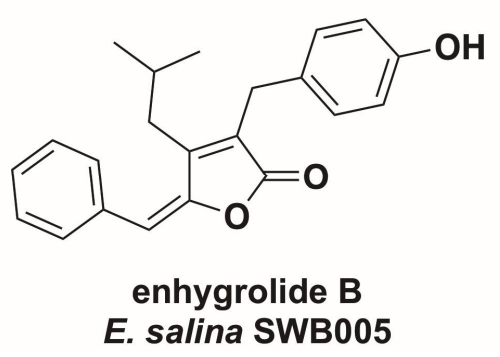

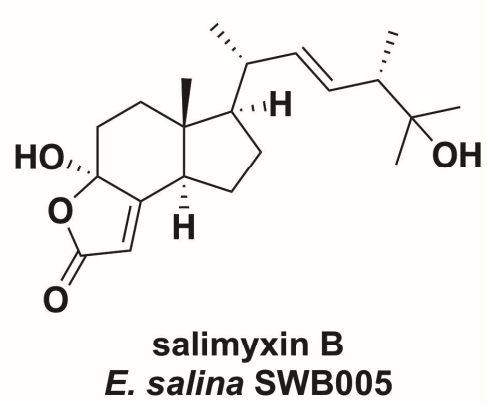

E. salina SWB005

Figure 3. Enhygromyxa salina secondary metabolites and hydroxyectoine $[20,43,44]$.

\section{Plesiocystis pacifica}

Discovered, yet again, by lizuka et al., P. pacifica, originally identified as Nannocystis sp. SHI-1, was isolated from a beach on Iriomote-jima Island, Japan in 1997 [12,28]. There are currently two reported strains, the type strain P. pacifica SIR $-1^{\mathrm{T}}$ (DSM 14875 ${ }^{\mathrm{T}}$ ) and SHI-1 (DSM 14876) [28]. Both strains produce pinkish-orange to brownish-orange fruiting bodies when grown on $\mathrm{VY} / 2$ that is supplemented with salt water, and require $\mathrm{NaCl}$ concentrations of $1 \%(w / v)$ for growth with optimum salinities of 2.0-3.0\% [28]. P. pacifica forms radial bands at the perimeter of its swarms, leaving cloudy etches in 
agar surfaces [28]. Similar to the other members of the Plesiocystis/Enhygromyxa clade of the suborder Nannocystineae, P. pacifica lyses Gram-negative bacteria and is unable to lyse S. cerevisiae [28]. While no secondary metabolites have been reported from either strain, an antiSMASH analysis on the draft genome of P. pacifica SIR-1 ${ }^{\mathrm{T}}$ (GCA_000170895.1) revealed numerous secondary metabolite biosynthetic pathways $[18,46]$. This analysis portrays $P$. pacifica as an excellent candidate for future natural product discovery efforts. Instead, the haloalkane dehalogenase DppA from P. pacifica SIR- $1^{\mathrm{T}}$ has garnered interest as a potential biocatalyst for bioremediation of aromatic pollutants [47,48]. DppA shows unique specificities towards brominated $\alpha, \beta$-haloalkanes, with no activity observed towards the chlorinated substrates [48]. Only briefly referenced in a PCR survey of polyketide synthase genes from various myxobacteria, genomic DNA from Plesiocystis sp. strain SIS-2 was found to contain several polyketide synthases [46]. However, whether Plesiocystis sp. strain SIS-2 is a third strain of P. pacifica or a unique member of the genera Plesiocystis remains unclear.

\section{Haliangium tepidum}

The lesser investigated of the marine members of the Haliangiaceae clade of the suborder Nannocystineae, Haliangium tepidum SMP-10 ${ }^{\mathrm{T}}$ (DSM 14436 ${ }^{\mathrm{T}}$ ) was first reported by Fudou et al. [29]. Found to be an obligate halophile, $H$. tepidum grows and produces fruiting bodies at salinities ranging from $0.5-6.0 \% \mathrm{NaCl}(w / v)$ [29]. H. tepidum is able to lyse both Gram-negative bacteria and S. cereviseae, and swarms in radial patterns leaving slime sheets slightly etched into agar surfaces [29]. As the species designation suggests, $\mathrm{H}$. tepidum grows at moderately warm temperatures when compared to other marine myxobacteria with an optimal temperature range of $37-40^{\circ} \mathrm{C}$ [29]. While no genome sequence data or discovered natural products have been reported, a PCR survey of myxobacterial genomic DNA found an abundance of polyketide synthases within the genome of H. tepidum [46].

\section{Potential Marine Myxobacteria}

While the six previously discussed marine myxobacteria are the best characterized to date, there have been several recently reported potential marine myxobacteria. Tomura et al. discovered three new myxobacterial natural products that were produced by Enhygromyxa niigataensis or Enhygromyxa sp. SNB-1 (Figure 4) [49]. With a 97\% similarity to the $16 \mathrm{~S}$ rRNA sequence of E. salina SWB004, E. niigataensis SNB-1 was determined to be a new species within the genera Enhygromyxa. Although the phylogenetic position of E. niigataensis would suggest that it is indeed a marine myxobacterium, the halotolerance levels and morphological features of the strain are currently unreported [49]. Originally isolated from a marsh bank in Shikoku, Japan, Pseudenhygromyxa salsuginis SYR-2T (DSM 21377T) develops fruiting bodies at $\mathrm{NaCl}$ concentrations of up to $2.5 \%(w / v)$, and forms slightly sunken, radial swarms [26]. However, P. salsuginis is not an obligate halophile [26]. Optimal growth conditions for P. salsuginis were determined to be somewhat saline between $0.2-1.0 \% \mathrm{NaCl}$ [26]. The species identifier for $P$. salsuginis, translated as "of brackish water", aptly summarizes this observation. The obligate halophile Paraliomyxa miuraensis SMH-27-4 produces a variety of halogenated hybrid polyketide-nonribosomal peptide metabolites (Figure 4) [50]. Although its halophilic nature strongly suggests the strain to be a marine myxobacterium, the morphological features for P. miuraensis at saline cultivation conditions have not been reported. 
Enhygromyxa niigataensis or Enhygromyxa sp. SNB-1

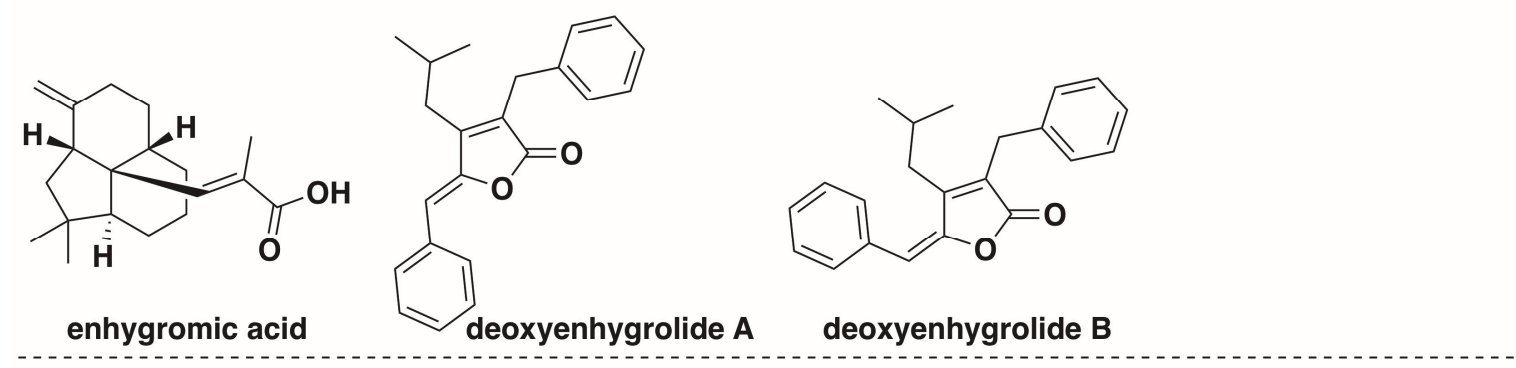

Paraliomyxa miuraensis strain SMH-27-4

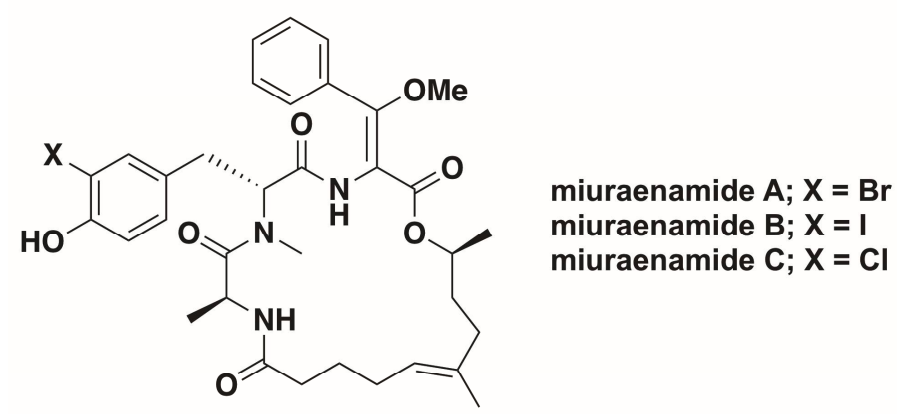<smiles>CO/C(=C(\NC(=O)[C@H](Cc1ccc(O)c(Br)c1)N(C)C(=O)[C@H](C)NC(=O)CCC/C=C(\C)CCC(C)OC(=O)c1ccccc1)C(=O)O)c1ccccc1</smiles>

miuraenamide D<smiles>CC(=O)CCC(C)OC(=O)C(NC(=O)[C@H](Cc1ccc(O)c(Br)c1)N(C)C(=O)C(C)NC(=O)CCCC=C(C)CC(C)C)C(=O)c1ccccc1</smiles>

miuraenamide $\mathrm{E}$<smiles>COC(=O)C(OC)=C(NC(=O)[C@H](Cc1ccc(O)c(Br)c1)N(C)C(=O)[C@H](C)NC(=O)CC(O)CC=C(C)CCC(C)OC)c1ccccc1</smiles>

miuraenamide $\mathbf{F}$

Figure 4. Secondary metabolites from potential marine myxobacteria [49-51].

\section{Conclusions}

Ubiquitous to marine environments worldwide, cultivable marine myxobacteria remain a relatively underexplored resource [31]. Ideally, this roll call for known marine myxobacteria and corresponding descriptions will provide clarity to the early literature surrounding halophilic and halotolerant myxobacteria, as well as encourage the continued discovery of new marine myxobacteria. The recent expansion of the order Myxococcales, with the addition of myxobacteria associated with the MMC, suggests that the vast majority of marine myxobacteria have yet to be discovered [31]. Although the limited number seems to suggest a scarcity, it should be recognized that the covered marine myxobacteria have been discovered thanks to the tremendous efforts of only a few research groups. This dearth of cultivable marine myxobacteria has not, however, limited the chemical diversity of their cognate reported natural products. To date, natural product classes discovered from marine and potential marine myxobacteria include polyketides, hybrid polyketide-nonribosomal peptides, degraded sterols, diterpenes, cyclic depsipeptides, and $\gamma$-alkylidenebutenolides. The capability to produce natural products with novel chemical scaffolds, such as salimabromide, will ensure the continued investigation of marine myxobacteria as a resource for the discovery of new therapeutics. 
Author Contributions: H.A. and D.C.S. compared marine myxobacterial genomes via BLAST and wrote the manuscript.

Funding: This research received no external funding.

Acknowledgments: We are grateful to Fulbright and AMIDEAST (H.A.), as well as the American Association of Colleges of Pharmacy New Investigator Award (D.C.S.) for support.

Conflicts of Interest: The authors declare no conflict of interest.

\section{References}

1. Reichenbach, H. The ecology of the myxobacteria. Environ. Microbiol. 1999, 1, 15-21. [CrossRef] [PubMed]

2. Stanier, R.Y. A Note on the Elasticotaxis in Myxobacteria. J. Bacteriol. 1942, 44, 405-412. [PubMed]

3. Stanier, R.Y. Studies on nonfruiting myxobacteria. I. Cytophaga johnsonae n. sp., a chitin-decomposing myxobacterium. J. Bacteriol. 1947, 53, 297-315. [PubMed]

4. Veldkamp, H. A Study on Two Marine Agar-Decomposing, Facultatively Anaerobic Myxobacteria. Microbiology 1961, 26, 331-342. [CrossRef] [PubMed]

5. Mitchell, T.G.; Hendrie, M.S.; Shewan, J.M. The Taxonomy, Differentiation and Identification of Cytophaga Species. J. Appl. Bacteriol. 1969, 32, 40-50. [CrossRef] [PubMed]

6. Brockman, E.R. Fruiting myxobacteria from the South Carolina coast. J. Bacteriol. 1967, 94, $1253-1254$. [PubMed]

7. Rückert, G. Investigations on the distribution of myxobacteria in substrates influenced by seawater with special reference to the island of Helgoland. Helogländer Meeresuntersuchungen 1984, 38, 179-184. [CrossRef]

8. Gray, J.P.; Herwig, R.P. Phylogenetic analysis of the bacterial communities in marine sediments. Appl. Environ. Microbiol. 1996, 62, 4049-4059. [PubMed]

9. Ravenschlag, K.; Sahm, K.; Pernthaler, J.; Amann, R. High bacterial diversity in permanently cold marine sediments. Appl. Environ. Microbiol. 1999, 65, 3982-3989. [PubMed]

10. Bernardet, J.F.; Segers, P.; Vancanneyt, M.; Berthe, F.; Kersters, K.; Vandamme, P. Cutting a Gordian Knot: Emended Classification and Description of the Genus Flavobacterium, Emended Description of the Family Flavobacteriaceae, and Proposal of Flavobacterium hydatis nom. nov. (Basonym, Cytophaga aquatilis Strohl and Tait 1978). Int. J. Syst. Bacteriol. 1996, 46, 128-148. [CrossRef]

11. Moyer, C.L.; Dobbs, F.C.; Karl, D.M. Phylogenetic diversity of the bacterial community from a microbial mat at an active, hydrothermal vent system, Loihi Seamount, Hawaii. Appl. Environ. Microbiol. 1995, 61, 1555-1562. [PubMed]

12. Iizuka, T.; Jojima, Y.; Fudou, R.; Yamanaka, S. Isolation of myxobacteria from the marine environment. FEMS Microbiol. Lett. 1998, 169, 317-322. [CrossRef] [PubMed]

13. Zhang, Y.Q.; Li, Y.Z.; Wang, B.; Wu, Z.H.; Zhang, C.Y.; Gong, X.; Qui, Z.J.; Zhang, Y. Characteristics and living patterns of marine myxobacterial isolates. Appl. Environ. Microbiol. 2005, 71, 3331-3336. [CrossRef] [PubMed]

14. Li, Z.F.; Li, X.; Liu, H.; Liu, X.; Han, K.; Wu, Z.H.; Hu, W.; Li, F.F.; Li, Y.Z. Genome sequence of the halotolerant marine bacterium Myxococcus fulvus HW-1. J. Bacteriol. 2011, 193, 5015-5016. [CrossRef] [PubMed]

15. Horton, T.; Kroh, A.; Ahyong, S.; Bailly, N.; Boury-Esnault, N.; Brandão, S.N.; Costello, M.J.; Gofas, S.; Hernandez, F.; Mees, J.; et al. World Register of Marine Species; WoRMS Editorial Board: Ostend, Belgium, 2018. Available online: http:/ / www.marinespecies.org (accessed on 1 May 2018). [CrossRef]

16. Pye, C.R.; Bertin, M.J.; Lokey, R.S.; Gerwick, W.H.; Linington, R.G. Retrospective analysis of natural products provides insights for future discovery trends. Proc. Natl. Acad. Sci. USA 2017, 114, 5601-5606. [CrossRef] [PubMed]

17. Herrmann, J.; Fayad, A.A.; Müller, R. Natural Products from myxobacteria: Novel metabolites and bioactivities. Nat. Prod. Rep. 2017, 34, 135-160. [CrossRef] [PubMed]

18. Dávila-Céspedes, A.; Hufendiek, P.; Crüsemann, M.; Schäberle, T.F.; König, G.M. Marine-derived myxobacteria of the suborder Nannocystineae: An underexplored source of structurally intriguing and biologically active metabolites. Beilstein J. Org. Chem. 2016, 12, 969-984. [CrossRef] [PubMed]

19. Schäberle, T.F.; Lohr, F.; Schmitz, A.; König, G.M. Antibiotics from myxobacteria. Nat. Prod. Rep. 2014, 31, 953-972. [CrossRef] [PubMed] 
20. Da Costa, M.S.; Santos, H.; Galinski, E.A. An overview of the role and diversity of compatible solute in Bacteria and Archaea. Adv. Biochem. Eng. Biotechnol. 1998, 61, 117-153. [PubMed]

21. Burg, M.B.; Ferraris, J.D. Intracellular organic osmolytes: Function and regulation. J. Biol. Chem. 2008, 283, 7309-7313. [CrossRef] [PubMed]

22. Moghaddam, J.A.; Boehringer, N.; Burdziak, A.; Kunte, H.; Galinski, E.A.; Schäberle, T.F. Different strategies of osmoadaptation in the closely related marine myxobacteria Enhygromyxa salina SWB007 and Plesiocystis pacifica SIR-1. Microbiology 2016, 162, 651-661. [CrossRef] [PubMed]

23. Schumacher, D.; Søgaard-Anderson, L. Regulation of Cell Polarity in Motility and Cell Division in Myxococcus xanthus. Annu. Rev. Microbiol. 2017, 71, 61-78. [CrossRef] [PubMed]

24. Muñoz-Dorado, J.; Marcos-Torres, F.J.; Garćia-Bravo, E.; Moraleda-Muñoz, A.; Pérez, J. Myxobacteria: Moving, Killing, Feeding, and Surviving Together. Front. Microbiol. 2016, 7, 781. [CrossRef] [PubMed]

25. Wang, B.; Hu, W.; Liu, H.; Zhang, C.Y.; Zhao, J.Y.; Jiang, D.M.; Wu, Z.H.; Li, Y.Z. Adaptation of Salt-tolerant Myxococcus Strains and their Motility Systems to the Ocean Conditions. Microb. Ecol. 2007, 54, 43-51. [CrossRef] [PubMed]

26. Iizuka, T.; Jojima, Y.; Hayakawa, A.; Fujii, T.; Yamanaka, S.; Fudou, R. Pseudenhygromyxa salsuginis gen. nov., sp. nov., a myxobacterium isolated from an estuarine marsh. Int. J. Syst. Evol. Microbiol. 2013, 63, 1360-1369. [CrossRef] [PubMed]

27. Iizuka, T.; Jojima, Y.; Fudou, R.; Tokura, M.; Hiraishi, A.; Yamanaka, S. Enhygromyxa salina gen. nov., sp. nov., a slightly halophilic myxobacterium isolated from the coastal areas of Japan. Syst. Appl. Microbiol. 2003, 26, 189-196. [CrossRef] [PubMed]

28. Iizuka, T.; Jojima, Y.; Fudou, R.; Hiraishi, A.; Ahn, J.W.; Yamanaka, S. Plesiocystis pacifica gen. nov., sp. nov., a marine myxobacterium that contains dehydrogenated menaquinone, isolated from the Pacific coasts of Japan. Int. J. Syst. Evol. Microbiol. 2003, 53, 189-195. [CrossRef] [PubMed]

29. Fudou, R.; Jojima, Y.; Iizuka, T.; Yamanaka, S. Haliangium ochraceum gen. nov., sp. nov. and Haliangium tepidum sp. nov.: Novel moderately halophilic myxobacteria isolated from coastal saline environments. J. Gen. Appl. Microbiol. 2002, 48, 109-116. [CrossRef] [PubMed]

30. Schäberle, T.F.; Goralski, E.; Neu, E.; Erol, O.; Hölzl, G.; Dörmann, P.; Bierbaum, G.; König, G.M. Marine myxobacteria as a source of antibiotics-Comparison of physiology, polyketide-type genes and antibiotic production of three new isolates of Enhygromyxa salina. Mar. Drugs 2010, 8, 2466-2479. [CrossRef] [PubMed]

31. Brinkhoff, T.; Fischer, D.; Vollmers, J.; Voget, S.; Beardsley, C.; Thole, S.; Mussmann, M.; Kunze, B.; Wagner-Döbler, I.; Daniel, R.; et al. Biogeography and phylogenetic diversity of a cluster of exclusively marine myxobacteria. ISME J. 2012, 6, 1260-1272. [CrossRef] [PubMed]

32. Jiang, D.M.; Kato, C.; Zhou, X.W.; Wu, Z.H.; Sato, T.; Li, Y.Z. Phylogeographic separation of marine and soil myxobacteria at high levels of classification. ISME J. 2010, 4, 1520-1530. [CrossRef] [PubMed]

33. Kumar, S.; Stecher, G.; Tamura, K. MEGA7: Molecular Evolutionary Genetics Analysis version 7.0 for bigger datasets. Mol. Biol. Evol. 2016, 33, 1870-1874. [CrossRef] [PubMed]

34. Ivanova, N.; Daum, C.; Lang, E.; Abt, B.; Kopitz, M.; Saunders, E.; Lapidus, A.; Lucas, S.; Glavina Del Rio, T.; Nolan, M.; et al. Complete genome sequence of Haliangium ochraceum type strain (SMP-2). Stand. Genom. Sci. 2010, 2, 96-106. [CrossRef] [PubMed]

35. Fudou, R.; Iizuka, T.; Yamanaka, S. Haliangicin, a novel antifungal metabolite produced by a marine myxobacterium. 1. Fermentation and biological characteristics. J. Antibiot. (Tokyo) 2001, 54, 149-152. [CrossRef] [PubMed]

36. Fudou, R.; Iizuka, T.; Sato, S.; Ando, T.; Shimba, N.; Yamanaka, S. Haliangicin, a novel antifungal metabolite produced by a marine myxobacterium. 2. Isolation and structural elucidation. J. Antibiot. (Tokyo) 2001, 54, 153-156. [CrossRef] [PubMed]

37. Kundim, B.A.; Itou, Y.; Sakagami, Y.; Fudou, R.; Iizuka, T.; Yamanaka, S.; Ojika, M. New haliangicin isomers, potent antifungal metabolites produced by a marine myxobacterium. J. Antibiot. (Tokyo) 2003, 56, 630-638. [CrossRef] [PubMed]

38. Sun, Y.; Feng, Z.; Tomura, T.; Suzuki, A.; Miyano, S.; Tsuge, T.; Mori, H.; Suh, J.-W.; Iizuka, T.; Fudou, R.; et al. Isolation and Biosynthetic Analysis of Haliamide, a New PKS-NRPS Hybrid Metabolite from the Marine Myxobacterium Haliangium ochraceum. Molecules 2016, 21, 59. [CrossRef] [PubMed] 
39. Sun, Y.; Feng, Z.; Tomura, T.; Suzuki, A.; Miyano, S.; Tsuge, T.; Mori, H.; Suh, J.; Iizuka, T.; Fudou, R.; et al. Heterologous Production of the Marine Myxobacterial Antibiotic Haliangicin and Its Unnatural Analogues Generated by Engineering of the Biochemical Pathway. Sci. Rep. 2016, 6, 22091. [CrossRef] [PubMed]

40. Timmermans, M.L.; Paudel, Y.P.; Ross, A.C. Investigating the Biosynthesis of Natural Products from Marine Proteobacteria: A Survey of Molecules and Strategies. Mar. Drugs 2017, 15, 235. [CrossRef] [PubMed]

41. Amiri Moghaddam, J.; Poehlein, A.; Fisch, K.; Alanjary, M.; Daniel, R.; König, G.M.; Schäberle, T.F. Draft Genome Sequences of the Obligatory Marine Myxobacterial Strains Enhygromyxa salina SWB005 and SWB007. Genome Announc. 2018, 6, e00324-18. [CrossRef] [PubMed]

42. Garcia, R.; Gerth, K.; Stadler, M.; Dogma, I.J.; Müller, R. Expanded phylogeny of myxobacteria and evidence for cultivation of the 'unculturables'. Mol. Phylogenet. Evol. 2010, 57, 878-887. [CrossRef] [PubMed]

43. Felder, S.; Felder, S.; Dreisigacker, S.; Kehraus, S.; Neu, E.; Bierbaum, G.; Wright, P.R.; Menche, D.; Schäberle, T.F.; König, G.M. Salimabromide: Unexpected chemistry from the obligate marine myxobacterium Enhygromyxa salina. Chemistry 2013, 19, 9319-9324. [CrossRef] [PubMed]

44. Felder, S.; Kehraus, S.; Neu, E.; Bierbaum, G.; Schäberle, T.F.; König, G.M. Salimyxins and enhygrolides: Antibiotic, sponge-related metabolites from the obligate marine myxobacterium Enhygromyxa salina. ChemBioChem 2013, 14, 1363-1371. [CrossRef] [PubMed]

45. Blin, K.; Wolf, T.; Chevrette, M.G.; Lu, X.; Schwalen, C.J.; Kautsar, S.A.; Suarez Duran, H.G.; de Los Santos, E.L.C.; Kim, H.U.; Nave, M.; et al. antiSMASH 4.0-improvements in chemistry prediction and gene cluster boundary identification. Nucleic Acids Res. 2017, 45, W36-W41. [CrossRef] [PubMed]

46. Komaki, H.; Fudou, R.; Iizuka, T.; Nakajima, D.; Okazaki, K.; Shibata, D.; Ojika, M.; Harayama, S. PCR detection of type I polyketide synthase genes in myxobacteria. Appl. Environ. Microbiol. 2008, 74, 5571-5574. [CrossRef] [PubMed]

47. Bogdanović, X.; Hesseler, M.; Palm, G.J.; Bornscheuer, U.T.; Hinrichs, W. Crystallization and preliminary X-ray diffraction studies of the putative haloalkane dehalogenase DppA from Plesiocystis pacifica SIR-1. Acta Crystallogr. Sect. F Struct. Biol. Cryst. Commun. 2010, 66, 828-830. [CrossRef] [PubMed]

48. Hesseler, M.; Bogdanović, X.; Hidalgo, A.; Berenguer, J.; Palm, G.J.; Hinrichs, W.; Bornscheuer, U.T. Cloning, functional expression, biochemical characterization, and structural analysis of a haloalkane dehalogenase from Plesiocystis pacifica SIR-1. Appl. Microbiol. Biotechnol. 2011, 91, 1049-1060. [CrossRef] [PubMed]

49. Tomura, T.; Nagashima, S.; Yamazaki, S.; Iizuka, T.; Fudou, R.; Ojika, M. An Unusual Diterpene-Enhygromic Acid and Deoxyenhygrolides from a Marine Myxobacterium, Enhygromyxa sp. Mar. Drugs 2017, 15, 109. [CrossRef] [PubMed]

50. Ojika, M.; Inukai, Y.; Kito, Y.; Hirata, M.; Iizuka, T.; Fudou, R. Miuraenamides: Antimicrobial cyclic depsipeptides isolated from a rare and slightly halophilic myxobacterium. Chem. Asian J. 2008, 3, 126-133. [CrossRef] [PubMed]

51. Iizuka, T.; Fudou, R.; Jojima, Y.; Ogawa, S.; Yamanaka, S.; Inukai, Y.; Ojika, M. Miuraenamides A and B, Novel Antimicrobial Cyclic Depsipeptides from a New Slightly Halophilic Myxobacterium: Taxonomy, Production, and Biological Properties. J. Antibiot. 2006, 59, 385-391. [CrossRef] [PubMed]

(c) 2018 by the authors. Licensee MDPI, Basel, Switzerland. This article is an open access article distributed under the terms and conditions of the Creative Commons Attribution (CC BY) license (http://creativecommons.org/licenses/by/4.0/). 